\title{
Leaf mineral composition of grafted eggplant grown in soil infested with Verticillium and root-knot nematodes
}

\author{
Sebahattin Çürük(1), H. Yildiz Dasgan (2), Sedat Mansuroğlu(1), Şener Kurt'(3), \\ Meltem Mazmanoğlu(2), Gülcan Tarla(4) and Coşkun Durgaç(1)
}

\begin{abstract}
(1)Mustafa Kemal University (MKU), Department of Horticulture, Faculty of Agriculture, 31034 Antakya-Hatay, Turkey. E-mail: sebahattincuruk@gmail. com, semansoft@hotmail.com, cdurgac@mku.edu.tr (2)Çukurova University, Department of Horticulture, Faculty of Agriculture, Balcall, 01330 Adana, Turkey.E-mail: dasgan@cu.edu.tr, melmazman@hotmail.com ${ }^{(3)} \mathrm{MKU}$, Department of Plant Protection, Faculty of Agriculture. E-mail:kurt@mku.edu.tr (4)Uşak University, Department of Organic Farming, Eşme Technical Vocational School of Higher Education, Uşak, Turkey. E-mail: gulcan.tarla@usak.edu.tr
\end{abstract}

\begin{abstract}
The objective of this work was to determine differences in leaf mineral composition between ungrafted and grafted onto (Solanum torvum) eggplant (Solanum melongena), cultivars 'Faselis' and 'Pala', grown in a soil infested with Verticillium dahliae and Meloidogyne incognita, or in a noninfested soil. Grafting increased leaf $\mathrm{P}$ and $\mathrm{Mn}$ concentrations, and decreased $\mathrm{N}$ concentrations, in both soils. Grafting also enhanced leaf Ca concentration of 'Pala', but it did not affect that of 'Faselis' depending on the cropping year. Leaf Mg concentration of grafted plants in infested soil was lower than that of ungrafted ones in noninfested soil. Results showed that, under the same fertilization program, the grafted 'Faselis' plants used the nutrients more efficiently than the 'Pala' ones. Use of $S$. torvum as a rootstock for 'Faselis' resulted in an effective protection against multiple pathogen infestation. Fertilization may be necessary when grafted 'Faselis' plants are grown in a soil infested with the pathogens, since grafting and infestation generally decrease leaf $\mathrm{N}, \mathrm{Mg}, \mathrm{Ca}$ and $\mathrm{Fe}$ concentrations, either by reducing the nutrient concentrations directly or by increasing leaf $\mathrm{Mn}$ concentration.

Index terms: Meloidogyne incognita, Solanum melongena, Solanum torvum, mineral nutrition, multiple pathogen infestation.

\section{Composição mineral de folhas de berinjela enxertada e cultivada em solos infestados com Verticillium e nematóide-das-galhas}

\begin{abstract}
Resumo - O objetivo deste trabalho foi determinar as diferenças de composição mineral das folhas entre as cultivares de berinjela (Solanum melongena), 'Faselis' e 'Pala', enxertadas em Solanum torvum ou não enxertadas, e plantadas em solos infestados ou não com Verticillium dahliae e Meloidogyne incognita. A enxertia aumentou as concentrações de $\mathrm{P}$ e $\mathrm{Mn}$ nas folhas e diminuiu as de nitrogênio, em ambos os solos. A enxertia também aumentou a concentração de Ca foliar em 'Pala', mas não em 'Faselis', conforme o ano agrícola. A concentração de $\mathrm{Mg}$ foliar, em plantas enxertadas em solo infestado, foi menor que a de plantas não enxertadas em solo não infestado. Com um mesmo programa de adubação, as plantas enxertadas de 'Faselis' utilizaram os nutrientes de maneira mais eficiente que as de 'Pala'. O uso de $S$. torvum como porta-enxerto para Faselis, em solo contaminado com os patógenos resultou em proteção efetiva contra a infestação múltipla por patógenos. Fertilizações podem ser necessárias quando plantas enxertadas de 'Faselis' são cultivadas em solos infestados, já que a enxertia e a infestação geralmente reduzem as concentrações foliares de $\mathrm{N}, \mathrm{Mg}, \mathrm{Ca}$ and $\mathrm{Fe}$, seja pela redução direta nos teores dos nutrientes, seja pelo aumento da concentração foliar de Mn. .
\end{abstract}

Termos para indexação: Meloidogyne incognita, Solanum melongena, Solanum torvum, nutrição mineral, infestação múltipla por patógenos.

\section{Introduction}

Eggplant (Solanum melongena L.) is susceptible to numerous diseases and parasites, particularly bacterial ones, Fusarium and Verticillium wilts, nematodes and insects (Collonnier et al., 2001). Soil-borne pathogens and pests such as Verticillium, Fusarium and Meloidogyne spp. may cause up to $78 \%$ yield losses (Bletsos et al., 2003). Difficulties in chemical control of these diseases, absence of crop rotation, and sexual barriers between eggplant and its wild relatives that hinder breeding indicate that the only short term practical solution for the problem is to graft susceptible eggplant cultivars onto rootstocks with multiple pathogen resistance (Bletsos et al., 2003). Plant production by grafting has become a common practice to control soil-borne pathogens, especially for some Cucurbitaceae and Solanaceae species in greenhouses 
in Japan, Korea, China and in some Asian and European countries (Lee, 1994; King et al., 2008).

Eggplant is a popular vegetable in Turkey, and protected cultivation accounts for $20 \%$ of the total production. Grafting is a popular technique in protected cultivation of watermelon and melon in Turkey. However, although commercial growing of eggplant is constrained due to soil-borne pathogens such as Verticillium dahliae (Altınok \& Kamberoğlu, 2005) and Meloidogyne incognita (root-knot nematode) (Elekçioğlu et al., 1994), grafting in eggplant is not a common practice even in protected cultivation. Grafting of eggplant on rootstocks with multiple pathogen resistance may be used intensively in protected cultivation in the near future.

The most common rootstocks for eggplant are tomato (Ioannou, 2001) and related wild species such as Solanum torvum Sw., Solanum integrifolium Poir. and Solanum sisymbriifolium Lam. (Lee, 1994; Bletsos et al., 2003). Solanum torvum was reported to be resistant to Verticillium and bacterial wilts, root-knot nematode, and mycoplasma (Collonnier et al., 2001; Kashyap et al., 2003). Bletsos et al. (2003) have found that grafting of eggplant onto $S$. torvum and S. sisymbriifolium had positive effects on plant growth, yield and resistance to the incidence of $V$. dahliae, without changing fruit quality. The method of disease control provided by grafting is not well understood. It is presumed that the primary method is by avoidance, when the rootstock is resistant to the pathogen. This has been confirmed by observations in which suckers or other intact roots from the scion confer susceptibility to the grafted plant (King et al., 2008). Another mechanism is the allelopathic suppression exhibited by the root exudates from the rootstock. Root exudates from tomato rootstocks of eggplants were shown to directly inhibit the spore germination and mycelium growth of Verticillium wilt, while the root exudates of ungrafted eggplants enhanced the mycelium growth (Liu et al., 2009).

Grafting may influence plant vigor expressed through variations in growth, yield and product quality. The mechanisms that determine these effects can be diverse and can be attributed to the synthesis and translocation of plant growth regulators, to the size of the root system, and to water and nutrient uptake and assimilation (Lee, 1994; Leonardi \& Giuffrida, 2006). Available information on grafted plants nutrition is not exhaustive, and in many cases is limited to cucurbits (Ruiz et al., 1997; Pulgar et al., 2000; Colla et al., 2006; Leonardi \& Giuffrida, 2006).

Pathogens alter the nutrition of the plant in diverse ways. Some pathogens may immobilize nutrients in the rhizosphere or in the infected tissues; others impair the translocation and utilization of nutrients directly by malfunctioning of the vascular system, while still others cause deficiency or hyper accumulation and nutrient toxicity by changing membrane permeability, or mobilization toward infection sites (Huber, 1978; Huber \& Graham, 1999). Sometimes, different pathogens infect the crops simultaneously. Several reports implicate nematode root-knot lesions in breaking down the resistance of tomato, eggplant, cotton and peppermint plants to Fusarium or Verticillium wilts, due to the increase in disease severity (Hasan \& Khan, 1985; Katsantonis et al., 2005). Katsantonis et al. (2005) reported that root-knot nematode infestation in cotton could cause a decrease in total protein and carbohydrate levels and an increase in peroxidase activity in xylem fluids. These could be the mechanisms by which infection by Fusarium or Verticillium wilts is enhanced by root-knot nematode invasion. There are few reports concerning the effects of different rootstocks on mineral uptake and nutrition in tomato and eggplant (Suzuki \& Morishita, 2002; Leonardi \& Giuffrida, 2006; Arao et al., 2008), and there are no reports on the effect of $S$. torvum rootstock on leaf mineral composition when soil is infested with multiple pathogens.

The objective of this study was to investigate the effect of grafting eggplant onto $S$. torvum on leaf mineral composition of eggplant cultivars 'Faselis' and 'Pala' grown in noninfested or infested soils with $V$. dahliae Kleb. and M. incognita.

\section{Materials and Methods}

The experiments were carried out in the 2003/2004 and 2004/2005 growing seasons, in an unheated greenhouse, at the Agricultural Research Station of Mustafa Kemal University, Antakya, in the Southeastern Mediterranean Region of Turkey. The area is in the Amik plain, near $36^{\circ} 19^{\prime} \mathrm{N}$ and $36^{\circ} 11^{\prime} \mathrm{E}$, at 100 meters above sea level. Total annual rainfall at the study site was $1,155 \mathrm{~mm}$ in 2003/2004 and $750 \mathrm{~mm}$ in $2004 / 2005$. No rainfall occurred in June-July during the

Pesq. agropec. bras., Brasília, v.45, n.8, p.879-885, ago. 2010 
first cropping period. Average maximum, minimum and mean air temperatures were about 21.0, 12.5 and $16.2-17.0^{\circ} \mathrm{C}$, respectively, in the cropping periods of both years. The mean relative humidity was ca. 69 and $67 \%$ during the 2003/2004 and 2004/2005 growing periods, respectively. Plants were grown in a greenhouse with steel structure, with $12.8 \mathrm{~m}$ width span, $2.5 \mathrm{~m}$ gutter height, $4.5 \mathrm{~m}$ ridge height, continuous roof $(1 \mathrm{~m})$ and side $(1.2 \mathrm{~m})$ ventilation windows. Average maximum, minimum, and mean air temperatures and relative humidity inside the greenhouse were approximately 32.5, 15.3, and $22.6^{\circ} \mathrm{C}$, and $95.8,47.2,74.5 \%$, respectively. The growing medium was a soil mixture with $\mathrm{pH} 7.49$ composed of sand (49\%), clay (27\%) and loam (24\%) (SCL), and with electric conductivity of $1.58 \mathrm{~S} \mathrm{~m}^{-1}$, cation exchangeable capacity of $26.3 \mathrm{cmol}_{\mathrm{c}} \mathrm{kg}^{-1}$, $\mathrm{CaCO}_{3} 87 \mathrm{~g} \mathrm{~kg}^{-1}, \mathrm{~N} 360 \mathrm{~kg} \mathrm{ha}^{-1}, \mathrm{P}_{2} \mathrm{O}_{5} 18.3 \mathrm{~kg} \mathrm{ha}^{-1}, \mathrm{~K}_{2} \mathrm{O}$ $514 \mathrm{mg} \mathrm{kg}^{-1}$. The soil was disinfested by solarization for six weeks (Çürük et al., 2009).

The experimental design consisted of a factorial randomized complete block in a split plot arrangement, with three replicates per treatment. The factor pathogen (noninfested or infested soil with $V$. dahliae and $M$. incognita) was assigned to the main plots of each block; and cultivar ('Pala' or 'Faselis' $F_{1}$ ) and grafting (grafted on $S$. torvum or nongrafted) factorial combinations were randomly assigned to the subplots of each main plot. Based on soil analysis, the total amount of applied $\mathrm{N}-\mathrm{P}_{2} \mathrm{O}_{5}-\mathrm{K}_{2} \mathrm{O}$ was $980-260-1,560 \mathrm{~kg} \mathrm{ha}^{-1}$ (Savvas et al., 2008). All the manure and the fertilizer applied before planting were immediately incorporated into the soil. The fertilizer applied after planting was dissolved in water before using. Grafting by the budding method was used to produce grafted eggplant plantlets (Çürük et al., 2009). Seeds of cultivars 'Faselis' $F_{1}$ (De Ruiter Seeds, Bergschenhoek Holland) and 'Pala' (Atatürk Central Research Institute, Yalova-Bursa, Turkey) were sown in a sterile substrate, composed of $50 \%$ peat and perlite, in August of 2003 and 2004. Ungrafted control and grafted transplants with 5-6 leaves were transplanted to plastic bags containing $25 \mathrm{~L}$ of above mentioned soil mixture. Transplanting was on $15^{\text {th }}$ and $22^{\text {nd }}$ October in 2003 and 2004, respectively, at a density of 2.66 plants $\mathrm{m}^{-2}(0.75 \times 0.5 \mathrm{~m})$. Grafted and control seedlings had similar height and leaf number at this stage. Unless otherwise noted, measurements were made on five plants per replicate.
Verticillium dahliae $\mathrm{EgVd} 3$ isolates and egg masses of $M$. incognita were obtained from diseased eggplants and inoculated in the soil about two and four weeks after transplanting, respectively (Çürük et al., 2009). For Verticilium inoculation, conidial suspension was adjusted to a concentration of $10^{6}$ conidia $\mathrm{mL}^{-1}$ with a hemacytometer. The conidial suspension $(250 \mathrm{~mL})$ was added to the substrate around each seedling using a micropipette. Each plant used in the infested plot was infected with 1,200 nematode eggs placed into a $5-\mathrm{cm}$ depth hole near the roots. Leaf symptoms and disease indices were calculated as reported by Çürük et al. (2009).

Plant analyses for nitrogen, phosphorus, potassium, calcium, magnesium, iron, manganese, zinc and copper were carried out to compare the nutritional status of eggplant plants grown under the different treatments. In both cropping years, leaf samples (most-recently-matured whole leaf plus petiole) were collected approximately six months after transplanting, and dried at $65^{\circ} \mathrm{C}$ for 72 hours. After drying, the samples were ground to 20 mesh sieve size. Tissue powder was ashed at $550^{\circ} \mathrm{C}$ for about eight hours and dissolved in $3.3 \% \mathrm{HCl}$. The concentrations of $\mathrm{K}, \mathrm{Ca}, \mathrm{Mg}, \mathrm{Fe}, \mathrm{Mn}$, $\mathrm{Zn}$ and $\mathrm{Cu}$ were assessed through atomic absorption spectrophotometry (Jones Junior, 1972; Analytical methods for atomic absorption spectrophotometry, 1976). Nitrogen and $P$ concentrations were determined by the Kjeldahl and Barton methods, respectively (Jones Junior et al., 1991).

Statistical analyzes were done using SAS (SAS Institute, 1999) and MSTAT-C (Freed \& Eisensmith, 1989). When year or interactions involving year were not significant, data of the two cropping years were combined and analyzed by a general linear model (GLM) ANOVA, and means were shown. Otherwise, data of each year were analyzed and shown separately. Duncan's multiple range test was used for pairwise comparisons.

\section{Results and Discussion}

The leaf $\mathrm{N}, \mathrm{P}, \mathrm{Mg}$ and $\mathrm{Cu}$ concentrations were not significantly affected by year or interactions involving year. Therefore, the average data of the two years were presented for these variables (Table 1). Leaf $\mathrm{N}$ concentration was affected by grafting, but not by pathogen or cultivar. Grafting decreased leaf 
$\mathrm{N}$ concentration from 48.2 to $45.0 \mathrm{~g} \mathrm{~kg}^{-1}(6.6 \%)$. Grafted plants generally have bigger shoots than ungrafted ones, especially in the 'Pala' cultivar (Çürük et al., 2009). This may have caused a dilution effect, which would explain the lower $\mathrm{N}$ concentrations in grafted eggplants. It was reported that leaf nitrogen concentration decreased in watermelon grafted on pumpkin squash (Pulgar et al., 2000). However, it has been found that grafting increased leaf $\mathrm{N}$ concentration in eggplant (Leonardi \& Giuffrida, 2006), tomato (Fernandez-Garcia et al., 2004) and cucumber (Rouphael et al., 2008) grafted onto tomato or interspecific hybrid rootstocks, tomato rootstock, and Cucurbita maxima x C. moschata hybrid, respectively. According to Ruiz et al. (1997), the effect of grafting on leaf $\mathrm{N}$ concentration in melon differed depending on the rootstocks (C. maxima $\mathrm{x}$ C. moschata hybrids) used.

Cultivar, grafting and pathogen-grafting interactions were significant concerning leaf $\mathrm{P}$ concentration. The average $\mathrm{P}$ concentration of 'Pala' $\left(5.59 \mathrm{~g} \mathrm{~kg}^{-1}\right)$ was $20.2 \%$ greater than that of 'Faselis' $\left(4.65 \mathrm{~g} \mathrm{~kg}^{-1}\right)$. In noninfested and infested soil, leaf $\mathrm{P}$ concentrations of grafted plants (6.19 and $5.42 \mathrm{~g} \mathrm{~kg}^{-1}$ ) were $45 \%$ and $17.6 \%$ higher than those of ungrafted ones (4.27 and $\left.4.61 \mathrm{~g} \mathrm{~kg}^{-1}\right)$, respectively. There is a consensus in the literature that grafting increases leaf $\mathrm{P}$ concentration of some plants such as eggplant (Leonardi \& Giuffrida, 2006), cucumber (Rouphael et al., 2008) and tomato (Fernandez-Garcia et al., 2004).

The effects of grafting, cultivar, pathogen-grafting and pathogen-cultivar interaction on leaf $\mathrm{Mg}$ concentration were significant. By grafting, leaf $\mathrm{Mg}$ concentration decreased by $53.6 \%$ (from 7.89 to $\left.3.66 \mathrm{~g} \mathrm{~kg}^{-1}\right)$ in noninfested soil, but increased by $42.3 \%$ (from 4.49 to $6.39 \mathrm{~g} \mathrm{~kg}^{-1}$ ) in infested soil.
Furthermore, leaf $\mathrm{Mg}$ concentration of ungrafted plants in noninfested soil $\left(7.89 \mathrm{~g} \mathrm{~kg}^{-1}\right)$ was $19 \%$ greater than that of grafted ones in infested soil $\left(6.39 \mathrm{~g} \mathrm{~kg}^{-1}\right)$. Rouphael et al. (2008) and Ruiz et al. (1997) reported that grafting did not affect leaf $\mathrm{Mg}$ concentration in cucumber and melon. A similar result was reported by Leonardi \& Giuffrida (2006), regarding Mg uptake in eggplant grafted on tomato or interspecific tomato hybrids. Fernandez-Garcia et al. (2004) suggested that leaf $\mathrm{Mg}$ concentration of tomato grafted onto tomato rootstock was either higher or similar to the ungrafted ones. In the present study, infestation reduced leaf $\mathrm{Mg}$ concentration (from 5.61 to $4.24 \mathrm{~g} \mathrm{~kg}^{-1}$ ) by $24.4 \%$ in 'Pala', but in 'Faselis' the difference between leaf $\mathrm{Mg}$ concentration in infested $\left(6.64 \mathrm{~g} \mathrm{~kg}^{-1}\right)$ and noninfested $\left(5.94 \mathrm{~g} \mathrm{~kg}^{-1}\right)$ soils was not significant.

Leaf $\mathrm{Cu}$ concentration was not affected by pathogen, grafting, cultivar or interactions of these factors (Table 1). It was reported that there was no significant difference between leaf $\mathrm{Cu}$ concentration of grafted and ungrafted plants of cucumber grown on regular $\mathrm{Cu}$ concentration in the nutrient film technique (Rouphael et al., 2008).

Since leaf $\mathrm{K}, \mathrm{Ca}, \mathrm{Mn}, \mathrm{Fe}$ and $\mathrm{Zn}$ concentrations were significantly affected by year or interactions involving year, data of each year were analyzed and presented separately (Table 2). Leaf $\mathrm{K}$ concentration was affected by grafting, and grafting-cultivar interaction in $2003 / 2004$ and only by cultivar in $2004 / 2005$. Leaf $\mathrm{K}$ concentration of 'Pala' $\left(90.9 \mathrm{~g} \mathrm{~kg}^{-1}\right.$ ) was $46.4 \%$ higher than that of 'Faselis' $\left(62.1 \mathrm{~g} \mathrm{~kg}^{-1}\right)$ in $2004 / 2005$. In 2003/2004, however, leaf K concentration of 'Pala' $\left(38.7 \mathrm{~g} \mathrm{~kg}^{-1}\right)$ was $20.2 \%$ higher than that of 'Faselis' (32.2 $\mathrm{g} \mathrm{kg}^{-1}$ ) only in ungrafted plants. Higher $\mathrm{K}$ concentrations have been observed in grafted plants in cucumber (Rouphael et al., 2008) and tomato

Table 1. Leaf macro- and micronutrient average concentrations of the two cropping years 'Faselis' and 'Pala' of eggplant cultivars grown with or without rootstocks, in noninfested or infested (Vericillium dahliae and Meloidogyne incognita) soil.

\begin{tabular}{|c|c|c|c|c|c|c|c|c|}
\hline \multirow[t]{2}{*}{ Cultivar } & \multicolumn{2}{|c|}{$\mathrm{N}\left(\mathrm{g} \mathrm{kg}^{-1}\right)$} & \multicolumn{2}{|c|}{$P\left(\mathrm{~g} \mathrm{~kg}^{-1}\right)$} & \multicolumn{2}{|c|}{$\mathrm{Mg}\left(\mathrm{g} \mathrm{kg}^{-1}\right)$} & \multicolumn{2}{|c|}{$\mathrm{Cu}\left(\mathrm{mg} \mathrm{kg}^{-1}\right)$} \\
\hline & Ungrafted & Grafted & Ungrafted & Grafted & Ungrafted & Grafted & Ungrafted & Grafted \\
\hline & \multicolumn{8}{|c|}{ Noninfested soil } \\
\hline 'Faselis' & 45.1 & 44.2 & 3.73 & 5.86 & 8.37 & 3.52 & 13.3 & 14.7 \\
\hline \multirow[t]{2}{*}{ 'Pala' } & 46.3 & 42.4 & 4.82 & 6.53 & 7.41 & 3.81 & 17.9 & 13.5 \\
\hline & \multicolumn{8}{|c|}{ Infested soil } \\
\hline 'Faselis' & 52.1 & 47.3 & 4.22 & 4.80 & 5.83 & 7.45 & 17.2 & 13.8 \\
\hline 'Pala' & 49.3 & 45.9 & 5.00 & 6.03 & 3.14 & 5.34 & 18.8 & 9.2 \\
\hline$\overline{\mathrm{CV}(\%)}$ & \multicolumn{2}{|c|}{5.84} & \multicolumn{2}{|c|}{12.23} & \multicolumn{2}{|c|}{14.40} & \multicolumn{2}{|c|}{40.52} \\
\hline
\end{tabular}


(Fernandez-Garcia et al., 2004) in comparison to ungrafted ones. Ruiz et al. (1997) indicated that leaf $\mathrm{K}$ concentration in grafted melon was lower than that in ungrafted ones. It has also been reported that grafting did not affect leaf $\mathrm{K}$ concentration in watermelon (Colla et al., 2006) and eggplant (Leonardi \& Giuffrida, 2006).

Concerning leaf $\mathrm{Ca}$ concentration, grafting-cultivar interaction in both cropping years, and pathogen, cultivar and pathogen-grafting interaction in $2004 / 2005$ were significant. In 2003/2004, grafting increased leaf $\mathrm{Ca}$ concentration (from 21.1 to $30.3 \mathrm{~g} \mathrm{~kg}^{-1}$ ) significantly by $43.6 \%$ only in 'Pala'. In $2004 / 2005$, grafting enhanced leaf Ca concentration in 'Pala' by $22.2 \%$ (from 38.3 to $46.8 \mathrm{~g} \mathrm{~kg}^{-1}$ ), but reduced it in 'Faselis' by $15.3 \%$ (from 64.9 to $55.0 \mathrm{~g} \mathrm{~kg}^{-1}$ ). By infestation, leaf $\mathrm{Ca}$ concentration decreased by $28.8 \%$ in grafted plants (from 59.4 to $42.3 \mathrm{~g} \mathrm{~kg}^{-1}$ ), but the decrement in leaf $\mathrm{Ca}$ concentration in ungrafted ones (from 54.1 to $49.1 \mathrm{~g} \mathrm{~kg}^{-1}$ ) was not significant. It was reported that leaf $\mathrm{Ca}$ concentration increased in tomato by grafting onto tomato rootstock (Fernandez-Garcia et al., 2004). Arao et al. (2008) suggested that leaf-stem $\mathrm{Ca}$ concentrations of self-rooted eggplant cultivars were either higher than or similar to $S$. torvum in Cd-polluted soil. Ruiz et al. (1997) indicated that $\mathrm{Ca}$ concentration in grafted melon plants was not significantly different than that of ungrafted ones. In the present study, the internal fruit rot, as reported by Savvas et al. (2008), was infrequently observed in 'Faselis' relating to pathogen inoculation and grafting. Internal fruit rot is most likely to be a calcium-related physiological disorder caused by low $\mathrm{Ca}$ translocation to the fruit (Savvas et al., 2008).

Grafting in both cropping years significantly affected leaf $\mathrm{Mn}$ concentration. Leaf $\mathrm{Mn}$ concentrations of ungrafted plants in 2003/2004 and $2004 / 2005$ (70.6 and $73.5 \mathrm{mg} \mathrm{kg}^{-1}$, respectively) were 46.9 and $67.5 \%$ lower than those of grafted ones (133.0 and $\left.225.9 \mathrm{mg} \mathrm{kg}^{-1}\right)$. This finding is not consistent with the results by Rouphael et al. (2008), which showed that grafting did not affect leaf $\mathrm{Mn}$ concentration in cucumber. Arao et al. (2008) have reported that leaf-stem concentrations of self-rooted eggplant cultivars were similar to $S$. torvum. Leaf Mn concentration of 'Faselis' (106.4 $\mathrm{mg} \mathrm{kg}^{-1}$ ) was 9.5\% higher than that of 'Pala' $\left(97.2 \mathrm{mg} \mathrm{kg}^{-1}\right)$ in $2003 / 2004$, but the difference between the cultivars was not significant in 2004/2005.

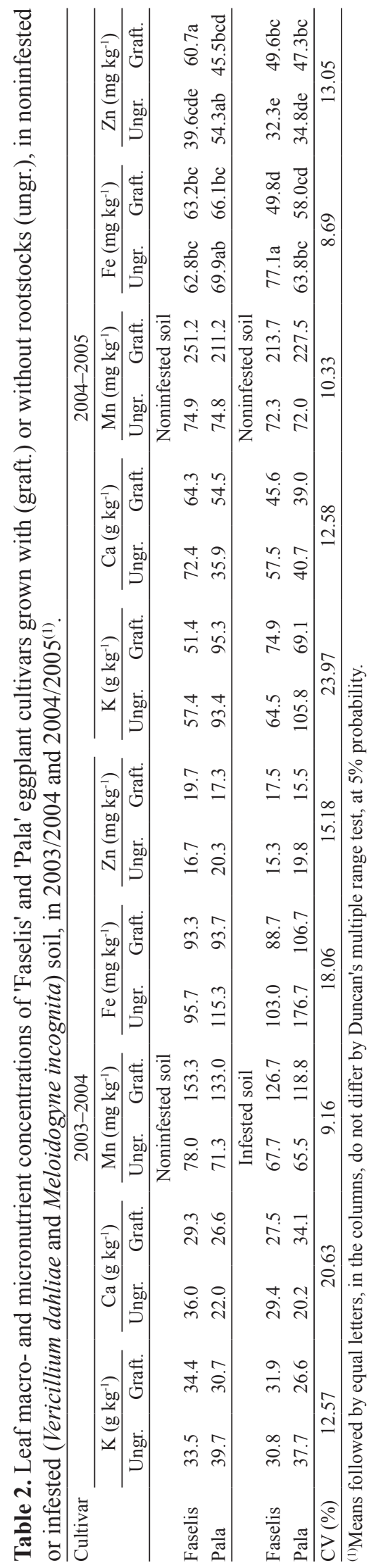

Pesq. agropec. bras., Brasília, v.45, n.8, p.879-885, ago. 2010 
Leaf $\mathrm{Fe}$ concentration was affected by grafting, cultivar, grafting-cultivar and pathogen-cultivar interactions in 2003/2004, and by grafting, pathogen-grafting and pathogen-grafting-cultivar interactions in 2004/2005. In 2003/2004, leaf Fe concentration of 'Pala' diminished $31.4 \%$ (from 146.0 to $100.2 \mathrm{mg} \mathrm{kg}^{-1}$ ) by grafting and increased $35.6 \%$ (from 104.5 to $141.7 \mathrm{mg} \mathrm{kg}^{-1}$ ) by infestation. In 2004/2005, leaf $\mathrm{Fe}$ concentration was enhanced $22.8 \%$ by infestation in ungrafted 'Faselis' plants, but it decreased $21.2 \%$ in grafted ones (Table 2). Iron deficiency symptoms that are induced by excess of Mn concentration, due to grafting, as reported by Savvas et al. (2008), were also observed in 'Faselis' during the winter periods of the experiments. Similar symptoms were also observed in S. torvum and were mild in the summer. Arao et al. (2008) reported that the differences in leaf-stem Fe concentrations, between self-rooted plants of $S$. melongena and S. torvum, were not significant, and that there were no significant differences between leaf-stem $\mathrm{Fe}$ concentrations of eggplants grafted on S. integrifolium and S. torvum. A similar result was reported by Rouphael et al. (2008).

Concerning leaf $\mathrm{Zn}$ concentration, grafting-cultivar interaction in 2003/2004, and pathogen, grafting, grafting-cultivar and pathogen-grafting-cultivar interactions in 2004/2005 were significant. In $2003 / 2004$, grafting reduced leaf $\mathrm{Zn}$ concentration by $18.4 \%$ (from 20.1 to $16.4 \mathrm{mg} \mathrm{kg}^{-1}$ ) in 'Pala', but with no significant differences in $\mathrm{Zn}$ concentration between grafted and ungrafted 'Faselis' plants. In 2004/2005, leaf Zn concentration in ungrafted 'Pala' and grafted 'Faselis' plants decreased $35.9 \%$ and $18.3 \%$, respectively, by infestation (Table 2). Arao et al. (2008) reported that leaf-stem $\mathrm{Zn}$ concentration of self-rooted $S$. torvum was higher than that of $S$. melongena, while there was no significant difference in leaf-stem $\mathrm{Zn}$ concentration in eggplant between grafted on S. torvum and on S. integrifolium. Rouphael et al. (2008) showed that grafting did not significantly affect $\mathrm{Zn}$ concentration of cucumber leaf.

In the present study, leaf analyses for $\mathrm{N}, \mathrm{P}, \mathrm{K}, \mathrm{Ca}$, $\mathrm{Mg}, \mathrm{Fe}, \mathrm{Zn}, \mathrm{Mn}$ and $\mathrm{Cu}$ showed that the eggplants in the experiments were adequately fed throughout the growth period. The ranges of nutrient concentrations recorded in control plants (ungrafted ones in noninfested soil) were within the order of "sufficient" for N, P, Mg, $\mathrm{Cu}, \mathrm{Mn}, \mathrm{Fe}$ and $\mathrm{Zn}$ in both cropping years and for $\mathrm{K}$ in 2003/2004, while they were higher than "sufficient" for $\mathrm{Ca}$ in both years and for $\mathrm{K}$ in 2004/2005 (Warr, 1993).

Vegetative growth and fruit yield were affected by cultivar characteristics according to Çürük et al. (2009). This could be attributed to the different growth characteristics, as 'Pala' is more vigorous and produces less fruit than 'Faselis'. This could also be attributed to the different graft affinity and compatibility with the rootstock. Solanum torvum is a vigorous rootstock, and graft combination of a vigorous cultivar with an equally vigorous rootstock reduced the amount of fertilizer required for the same yield (Suzuki \& Morishita, 2002). However, combination of a vigorous rootstock with a weak cultivar (Faselis) is more profitable than that of a vigorous rootstock with a vigorous cultivar (Pala) (Çürük et al., 2009). 'Faselis' also produced higher fruit yield than 'Pala' (Çürük et al., 2009). This showed that the grafted plants of 'Faselis' used the nutrients more efficiently than the 'Pala' ones. However, 'Faselis' may need additional nutrients, especially $\mathrm{N}, \mathrm{Mg}, \mathrm{Ca}$ and Fe during the winter, since the pathogens and grafting decrease the nutrients, either by reducing nutrient concentrations directly or by increasing leaf Mn concentration.

\section{Conclusions}

1. Grafting decreases leaf N concentration, regardless of soil infestation, and decreases $\mathrm{Mg}$ concentration in infested soil.

2. Grafting increases leaf $\mathrm{P}$ and $\mathrm{Mn}$ concentrations, regardless of soil infestation, and enhances $\mathrm{Ca}$ in 'Pala'.

3. Nutrients are more efficiently used by grafted 'Faselis' plants in comparison to 'Pala'.

4. 'Faselis' may need additional $\mathrm{N}, \mathrm{Mg}, \mathrm{Ca}$ and $\mathrm{Fe}$ fertilization when grafted onto Solanum torvum and grown in a soil infested with pathogens.

\section{Acknowledgements}

To Mustafa Kemal University, for funding the project; and to Dr. Mehmet Arslan, for reviewing the earlier version of the manuscript. 


\section{References}

ALTINOK, H.H.; KAMBEROĞLU, M.A. Adana ve Mersin illerinde patlıcan üretim alanlarında Fusarium ve Verticillium solgunluk hastalıklarının yaygınlığı ve şiddeti. Çukurova Üniversitesi Ziraat Fakültesi Dergisi, v.20, p.1-8, 2005.

ANALYTICAL methods for atomic absorption spectrophotometry. Norwalk: Perkin Elmer Corporation, 1976. Irregular paging.

ARAO, T.; TAKEDA, H.; NISHIHARA, E. Reduction of cadmium translocation from roots to shoots in eggplant (Solanum melongena) by grafting onto Solanum torvum rootstock. Soil Science and Plant Nutrition, v.54, p.555-559, 2008.

BLETSOS, F.; THANASSOULOPOULOS, C.; ROUPAKIAS, D. Effect of grafting on growth, yield, and Verticillium wilt of eggplant. HortScience, v.38, p.183-186, 2003.

COLLA, G.; ROUPHAEL, Y.; CARDARELLI, M.; REA, E. Effect of salinity on yield, fruit quality, leaf gas exchange, and mineral composition of grafted watermelon plants. HortScience, v.41, p.622-627, 2006.

COLLONNIER, C.; FOCK, I.; KASHYAP, V.; ROTINO, G.L.; DAUNAY, M.C.; LIAN, Y.; MARISKA, I.K.; RAJAM, M.V.; SERVAES, A.; DUCREUX, G.; SIHACHAKR, D. Applications of biotechnology in eggplant. Plant Cell, Tissue and Organ Culture, v.65, p.91-107, 2001.

ÇÜRÜK, S.; DASGAN, H.Y.; MANSUROĞLU, S.; KURT, Ş.; MAZMANOĞLU, M.; ANTAKLI, Ö.; TARLA, G. Grafted eggplant yield, quality and growth in infested soil with Verticillium dahliae and Meloidogyne incognita. Pesquisa Agropecuária Brasileira, v.44, p.1673-1681, 2009.

ELEKCIOGLU, J.H.; OHNESORGE, B.; LUNG, G.; UYGUN, N. Plant parasitic nematodes in the East Mediterranean region of Turkey. Nematologia Mediterranea, v.22, p.59-63, 1994.

FERNANDEZ-GARCIA, N.; MARTINEZ V.; CARVAJAL, M. Effect of salinity on growth, mineral composition, and water relations of grafted tomato plants. Journal of Plant Nutrition and Soil Science, v.167, p.616-622, 2004.

FREED, R.D.; EISENSMITH, S. MSTAT-C: a software package for the design, management, and analysis of agronomic experiments. East Lansing: Michigan State University, 1989.

HASAN, A.; KHAN, M.N. The effect of Rhizoctonia solani, Sclerotium rolfisii, and Verticillium dahliae on the resistance of tomato to Meloidogyne incognita. Nematologia Mediterranea, v.13, p.133-136, 1985.

HUBER, D.M. Disturbed mineral nutrition. In: HORSFALL, J.G.; COWLING, E.B. (Ed.). Plant disease: an advanced treatise: how plants suffer from disease. New York: Academic, 1978. v.3, p.163-181.

HUBER, D.M.; GRAHAM, R.D. The role of nutrition in crop resistance and tolerance to diseases. In: RENGEL, Z. Mineral nutrition of crops: fundamental mechanisms and implications. New York: Food Products, 1999. p.169-204.
IOANNOU, N. Integrating soil solarization with grafting on resistant rootstocks for management of soil-borne pathogens of eggplant. Journal of Horticultural Science and Biotechnology, v.76, p.396-401, 2001.

JONES JUNIOR, J.B. Plant tissue analysis for micronutrients. In: MORTVEDT, J.J.; GIORDANO, P.M.; LINDSAY, W.L. (Ed.). Micronutrients in agriculture. Madison: Soil Science Society of America, 1972. p.319-346.

JONES JUNIOR, J.B.; WOLF, B.; MILLS, H.A. Plant analysis handbook. Athens: Micro-Macro, 1991.213p.

KASHYAP,V:; KUMAR, S.V.; COLLONIER,C.;FUSARI,F.;HAICOUR, R.; ROTINO, G.L.; SIHACHAKR, D.; RAJAM, M.V. Biotechnology of eggplant. Scientia Horticulturae, v.97, p.1-25, 2003.

KATSANTONIS, D.; HILLOCKS, R.J.; GOWEN, S. Enhancement of germination of spores of Verticillium dahliae and Fusarium oxysporum $\mathrm{f} . \mathrm{sp}$. vasinfectum in vascular fluid from cotton plants infected with the root-knot nematode. Phytoparasitica, v.33, p.215-224, 2005.

KING, S.R.; DAVIS, A.R.; LIU, W.G.; LEVI, A. Grafting for disease resistance. HortScience, v.43, p.1673-1676, 2008.

LEE, J.M. Cultivation of grafted vegetables: I. Current status, grafting methods, and benefits. HortScience, v.29, p.235-239, 1994.

LEONARDI, C.; GIUFFRIDA, F. Variation of plant growth and macronutrient uptake in grafted tomatoes and eggplants on three different rootstocks. European Journal of Horticultural Science, v.71, p.97-101, 2006.

LIU, N.; ZHOU, B.; ZHAO, X.; LU, B.; LI, Y.; HAO, J. Grafting eggplant onto tomato rootstock to suppress Verticillium dahliae infection: the effect of root exudates. HortScience, v.44, p.2058-2062, 2009.

PULGAR, G.; VILLORA, G.; MORENO, DA.; ROMERO, L. Improving the mineral nutrition in grafted watermelon plants: nitrogen metabolism. Biologia Plantarum, v.43, p.607-609, 2000.

ROUPHAEL, Y.; CARDARELLI, M.; REA, E.; COLLA, G. Grafting of cucumber as a means to minimize copper toxicity. Environmental and Experimental Botany, v.63, p.49-58, 2008.

RUIZ, J.M.; BELAKBIR, A.; LOPEZ-CANTARERO, I.; ROMEROS, L. Leaf-macronutrient content and yield in grafted melon plants. A model to evaluate the influence of rootstock genotype. Scientia Horticulturae, v.71, p.227-234, 1997.

SAS INSTITUTE. SAS OnlineDoc. Version 8. Cary: SAS Institute, 1999. Available at: $<$ http://v8doc.sas.com/sashtml/ $>$. Accessed on: 25 Aug. 2010.

SAVVAS, D.; NTATSI, G.; PASSAM,H.C. Plant nutrition and physiological disorders in greenhouse grown tomato, pepper and eggplant. The European Journal of Plant Science and Biotechnology, v.2, p.45-61, 2008.

SUZUKI, T.; MORISHITA, M. Effects of scion and rootstock cultivars on growth and yield of eggplant cultured under two fertilizer levels. Journal of the Japanese Society for Horticultural Science, v.71, p.568-574, 2002.

WARR, C.W. Fertigation of vegetable crops. Manhattan: Kansas State University, 1993. 4p. Available at: <http://www.ksre.ksu.edu/ library/hort2/mf1092.pdf $>$. Accessed on: 25 Aug. 2010.

Received on April 30, 2010 and accepted June 21, 2010 